\title{
MAP3K3 wt Allele
}

National Cancer Institute

\section{Source}

National Cancer Institute. MAP3K3 wt Allele. NCI Thesaurus. Code C125113.

Human MAP3K3 wild-type allele is located in the vicinity of $17 q 23.3$ and is approximately $74 \mathrm{~kb}$ in length. This allele, which encodes mitogen-activated protein kinase kinase kinase 3 protein, is involved in protein phosphorylation and signal transduction. 